\title{
First record of Ptychoglossus brevifrontalis Boulenger, 1912 (Squamata, Alopoglossidae) in French Guiana
}

\author{
Maël Dewynter ${ }^{1}$, Laurent Godé ${ }^{2}$, Thierry Girardot ${ }^{2}$, Elodie Alice Courtois ${ }^{3}$
}

1 Indépendant, 1900 La Désirée, 97351 Matoury. French Guiana. 2 Parc Amazonien de Guyane, 1 rue Lederson, 97354 Rémire-Montjoly, French Guiana. 3 Laboratoire Ecologie, évolution, interactions des systèmes amazoniens (LEEISA), Université de Guyane, CNRS, IFREMER, 1635 Route de Montabo, 97300 Cayenne, French Guiana.

Corresponding author: Elodie Courtois, elodie.courtois@cnrs.fr

\begin{abstract}
One specimen of Ptychoglossus brevifrontalis Boulenger, 1912 was found during a field survey in the core area of the Amazonian National Park of French Guiana in the southern part of the country. Despite intensive herpetological surveys in French Guiana during the last three decades, this is the first record of the species for this country. This new locality extends the distribution of the species and draws attention to the need for more study of litter-dwelling lizards in French Guiana.
\end{abstract}

\section{Key words}

Guiana Shield, Herpetofauna, lizards, Neotropical region, Parc Amazonien de Guyane, South America.

Academic editor: Academic editor: Josué Anderson Rêgo Azevedo | Received 4 February 2019 | Accepted 18 July 2019 | Published 7 February 2020

Citation: Dewynter M, Godé L, Girardot T, Courtois EA (2019) First record of Ptychoglossus brevifrontalis Boulenger, 1912 (Squamata, Alopoglossidae) in French Guiana. Check List 16 (1): 155-161. https://doi.org/10.15560/16.1.155

\section{Introduction}

In the last three decades, there has been a growing effort to describe the extremely diverse herpetofauna of French Guiana. Numerous field surveys have been conducted, even in remote areas in the south of the country. Despite this effort, we still lack a comprehensive understanding of herpetofaunal diversity in French Guiana, especially for the Squamata. Within this group, most species display low detection probabilities and new country records or range extensions are still documented (e.g. Dewynter and Surugue 2012). One specimen of the litter-dwelling lizard Ptychoglossus brevifrontalis Boulenger, 1912 was recently found in a remote area of southern French Guiana (Mount Itoupé, south of Sommet Tabulaire mountain, Amazonian National Park of French Guiana). This is the first record of this species for French Guiana.
The genus Ptychoglossus Boulenger, 1912 comprises 14 described species (Peloso and Ávila-Pires 2010, Goicoechea et al. 2016), of which P. brevifrontalis displays the broadest geographic distribution (Peloso and Ávila-Pires 2010). It occurs from the foothills of the Andes to the eastern Amazonia (Anapu and Tocantins river basins) and the eastern Guiana Shield. Data from the literature indicate a broad geographic distribution in Brazil, Peru, Ecuador and Colombia (Ávila-Pires 1995, Pinto and Quatman 2005, Ávila-Pires et al. 2010, Peloso and Ávila-Pires 2010, Ribeiro-Junior and Amaral 2017), Colombia (Dunn 1944, Harris 1994), Ecuador (Boulenger 1912, Peters 1967, Duellman 1978, Harris 1994), Peru (Harris 1994, Carrillo de Espinoza and Icochea 1995), Venezuela (Barrio et al. 2003, Rivas et al. 2012), Bolivia (Harris 1994, Dirksen and De la Riva 1999) and 


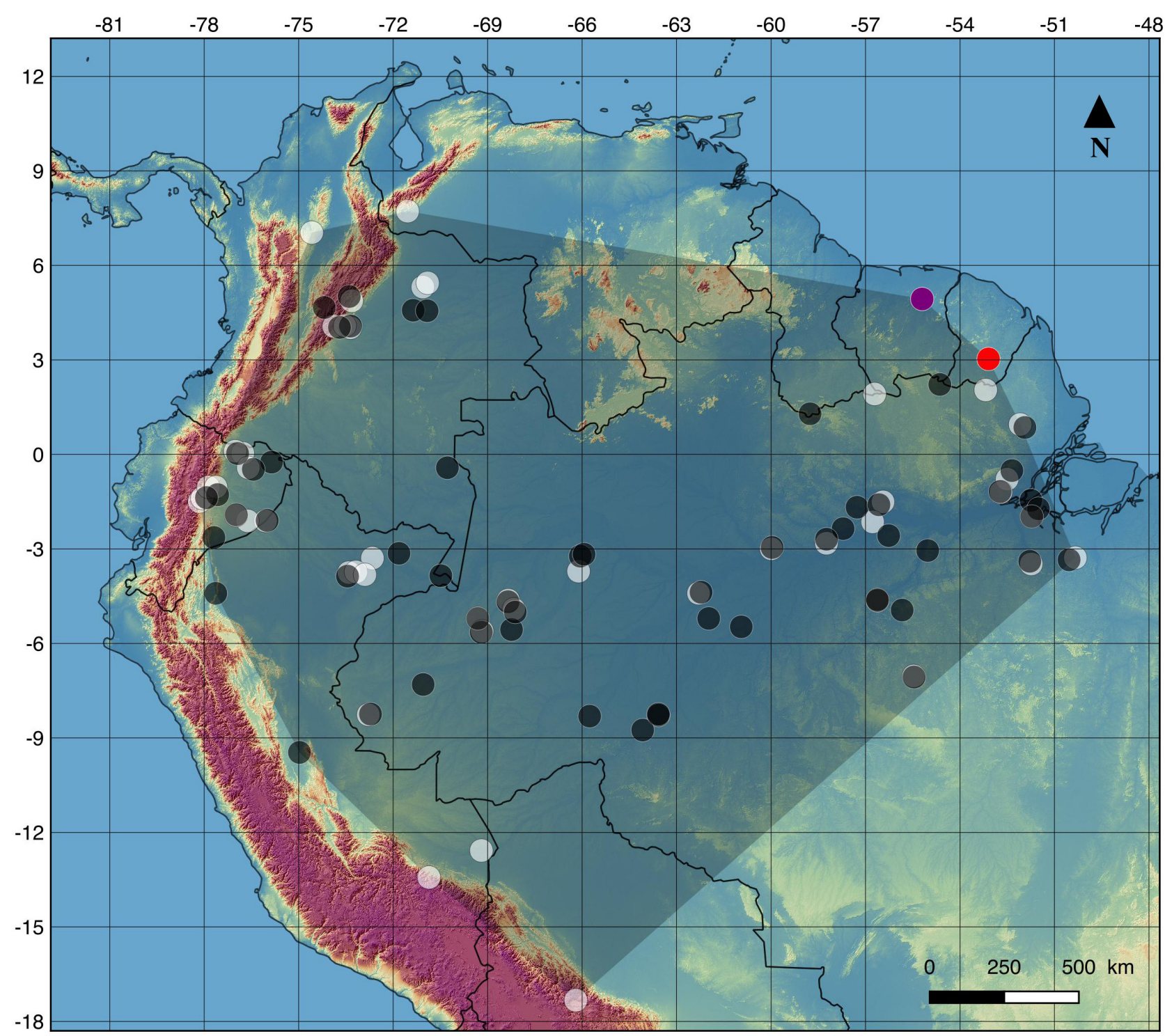

Figure 1. Range extension of Ptychoglossus brevifrontalis. Black dots: Data from Ribeiro-Junior and Amaral (2017). White dots: Data from Peloso and Ávila-Pires (2010). The gray dots represent overlapping points from the 2 previous studies. Purple dot: Data from Jairam and Jairam-Doerga (2016). Red dot: present study. The gray convex polygon represents the extent of occurrence (EOO) of the species.

Suriname (Hoogmoed 1973, Jairam and Jairam-Doerga 2016) (Fig. 1).

\section{Methods}

Mount Itoupé ("Mont Itoupé") is the second highest summit in French Guiana, after Mount Bellevue of the Inini (851 $\mathrm{m}$ a.s.1.). It is an elongated plateau positioned along a north-south axis, with a roughly $1 \mathrm{~km}^{2}$ flat summit reaching $830 \mathrm{~m}$ a.s.1. The plateau emerges from an imposing mountain range, situated $230 \mathrm{~km}$ inland, in the core area of the Amazonian National Park of French Guiana (Parc Amazonien de Guyane, Fig. 2). Most of the mountain range (about $45 \mathrm{~km}^{2}$ ) exceeds the $500 \mathrm{~m}$ isopleth considered as the lower limit of submontane forests. The rugged topography and high elevation affect the local climate by holding back the clouds. Annual rainfall measured in situ (3158 mm for October 2017 to October 2018) is much higher than what the data provided by WorldClim suggest (c. $2600 \mathrm{~mm}$, annual average
1970-2000, http://www.worldclim.org). Moreover, the high elevation contributes to maintenance of a persistent fog that keeps the upper slopes under extremely high levels of air moisture yearlong.

Mount Itoupé is entirely covered in forest, of which three main types can be seen: (1) an irregular high forest with many large emerging trees (up to $60 \mathrm{~m}$ tall) on the west-facing slope, (2) an irregular forest mixed with lianas on the east-facing side and (2) an open forest on the summit characterized by a low forest (20-30 m) with many tree gaps and a large proportion of trees belonging to typical heliophilous species (Sabatier et al. 2015). A herpetological survey was carried out at the end of the dry season, from 12 to 22 November 2018, mainly on the western slope and on the plateau of Mount Itoupé. During this period, mean temperature at the site was 23.7 ${ }^{\circ} \mathrm{C}$, mean relative humidity was $91.0 \%$ and $77.8 \mathrm{~mm}$ of rainfall occurred. The base camp and helicopter drop zone were set up at $585 \mathrm{~m}$ a.s.1. $\left(03^{\circ} 01^{\prime} 26^{\prime \prime} \mathrm{N}, 053^{\circ} 05^{\prime} 41^{\prime \prime}\right.$ 


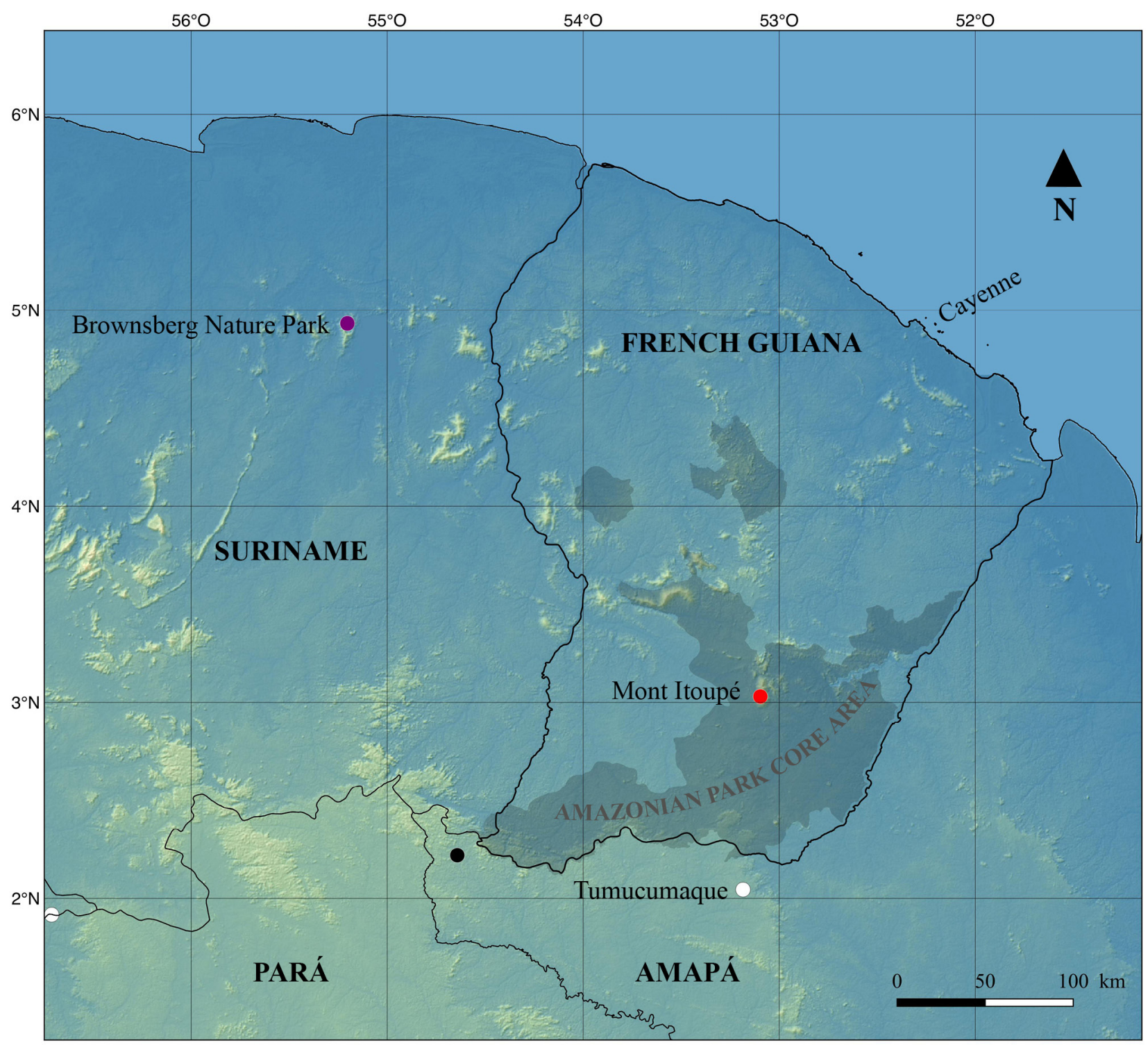

Figure 2. Localities of Ptychoglossus brevifrontalis in the eastern Guiana Shield. Black dots: data from Ribeiro-Junior and Amaral (2017). White dots: data from Peloso and Ávila-Pires (2010). Purple dot: data from Jairam and Jairam-Doerga (2016). Red dot: present study.

W). Four transects previously opened by the Amazonian Park of French Guiana team allowed us to explore an elevational gradient ranging from 350 to $830 \mathrm{~m}$.

\section{Results}

One adult gravid female Ptychoglossus brevifrontalis $(\mathrm{SVL}=55 \mathrm{~mm}$ and tail $=98 \mathrm{~mm}$, Fig. 3), with two oviducal eggs $(10 \times 5 \mathrm{~mm})$ was collected in the leaf litter $\left(03^{\circ} 02^{\prime} 23^{\prime \prime} \mathrm{N}, 053^{\circ} 06^{\prime} 15^{\prime \prime} \mathrm{W} ; 450 \mathrm{~m}\right.$ a.s.1.) by day on 20 November 2018 . The exact locality was a temporary pond that was dry at this time of the year with an open understory, and a high density of dead wood. Morphological characteristics of the living animal were carefully photographed and the animal was then euthanized by intraperitoneal injection of Xylocaine ${ }^{\circledR}$ (lidocaine hydrochloride). A tissue sample (liver) was removed and stored in $95 \%$ ethanol for molecular analyses. The specimen was fixed in $10 \%$ formalin before being transferred to a solution of $70 \%$ ethanol for permanent storage. The lizard was collected under Antoine Fouquet's permit number APA-973-23 and was deposited in the herpetological collection of the Muséum National d'Histoire Naturelle (MNHN) in Paris, France, under voucher number MNHN-RA 2018.0079.

New records. South America: French Guiana: Mont Itoupé $\left(03^{\circ} 02^{\prime} 23^{\prime \prime} \mathrm{N}, 053^{\circ} 06^{\prime} 15^{\prime \prime} \mathrm{W} ; 450 \mathrm{~m}\right.$ a.s.1.), collected by M. Dewynter and E.A. Courtois, 20 November 2018 (1 specimen, MNHN-RA 2018.0079, gravid female).

Identification. As it moves in the leaf litter, Ptychoglossus brevifrontalis is quite similar in its behavior to Arthrosaura versteegii Lidth de Jeude, 1904, a Gymnophthalmidae that is quite rare in French Guiana. An initial rapid examination of the lizard in the field led to a misidentification, but further careful examination of the specimen revealed deep morphological differences. In French Guiana, $P$. brevifrontalis can be confused with A. versteegii from which it mainly differs by the shape of the ventral plates (rounded posterior margins and 


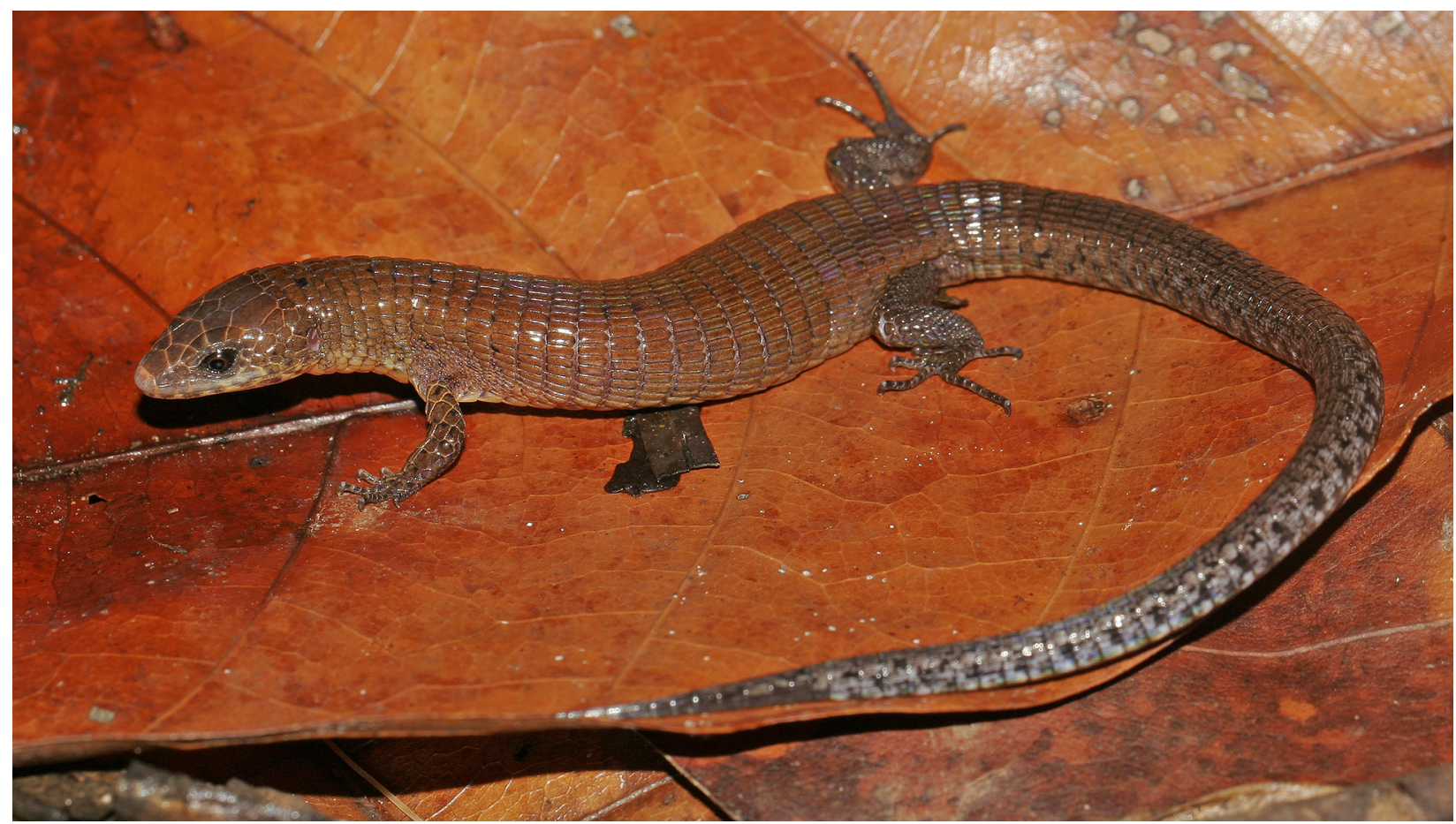

Figure 3. Adult female Ptychoglossus brevifrontalis from Mount Itoupé $(03.039864,-53.10411)$. Photograph by Maël Dewynter.

overlapping scales for $A$. versteegii and square without overlapping scales in $P$. brevifrontalis; Fig. 4). Moreover, in P. brevifrontalis, the caudal scales are truncate and juxtaposed while they are hexagonal in shape and overlap in $A$. versteegii. Furthermore, P. brevifrontalis has four supraoculars (Fig. 5), whereas A. versteegii has three (Peters 1967, Duellman 1978). Table 1 gives an overview of the measurements and scale counts for this individual compared to values in the literature (Harris 1994, Jairam and Jairam-Doerga 2016, Peloso and ÁvilaPires 2010).

\section{Discussion}

This finding extends the distribution of Ptychoglossus brevifrontalis in its north-east corner by approximately $100 \mathrm{~km}$. This discovery, in a site that has been visited several times in the past (2010, 2016, and 2017, totaling 40 days including this survey), highlights the low detection probability of litter-dwelling lizards. Two lizards are now known only from Mont Itoupé locality in French Guiana (Amapasaurus tetradactylus Cunha, 1970 (Dewynter and Surugue 2012) and P. brevifrontalis, present study) and should be intensively searched for at other localities to evaluate their conservation status in French Guiana.

\section{Acknowledgements}

The 2018 Itoupé expedition was funded by the French Guianan Amazonian National Park authorities ("Parc Amazonien de Guyane"). We thank Arnaud Anselin, Raphaëlle Rinaldo, and Stéphanie Scellier for their support, Nicolas Vidal (MNHN) for providing the voucher number, and Jessica Deichmann, Marco Ribeiro-Junior and Josué Anderson Rêgo Azevedo for comments on earlier version of the manuscript.

\section{Authors' Contributions}

EAC, MD, TG, and LG collected the specimen; MD and EAC identified and photographed the specimen; MD and EAC wrote the manuscript; all authors reviewed the text.

\section{References}

Boulenger GA (1912) Descriptions of new reptiles from the Andes of South America, preserved in the British Museum. The Annals

Table 1. A comparison of the Ptychoglossus brevifrontalis specimen (adult female) collected in French Guiana with a young female from Suriname (National Zoological Collection of Suriname NZCS R679 Jairam and Jairam-Doerga 2016), 35 specimens from Harris (1994) and 13 specimens from Peloso and Ávila-Pires (2010).

\begin{tabular}{lllll}
\hline Traits & $\begin{array}{l}\text { MNHN-RA 2018.0079 } \\
\text { (present study) }\end{array}$ & $\begin{array}{l}\text { Harris 1994 } \\
(\mathbf{N = 3 5 )}\end{array}$ & $\begin{array}{l}\text { Peloso and Ávila-Pires } \\
\mathbf{2 0 1 0}(\mathbf{N}=\mathbf{1 3})\end{array}$ & $\begin{array}{l}\text { NZCS R679 (Jairam and Jairam- } \\
\text { Doerga 2016) }\end{array}$ \\
\hline Snout-vent length (mm) & 55 & 60 & $38-56.4$ (Females) & 25.4 \\
Tail length (mm) & 98 & 92 & NA & 26.5 \\
No. of scales around mid-body & 31 & $28-36$ & $28-34$ & 26 \\
No. of transverse rows of ventral & 17 & $16-21$ & $17-20$ & 19 \\
Number of supralabials & 7 & $6-8$ & $7-8$ & 6 \\
\hline
\end{tabular}




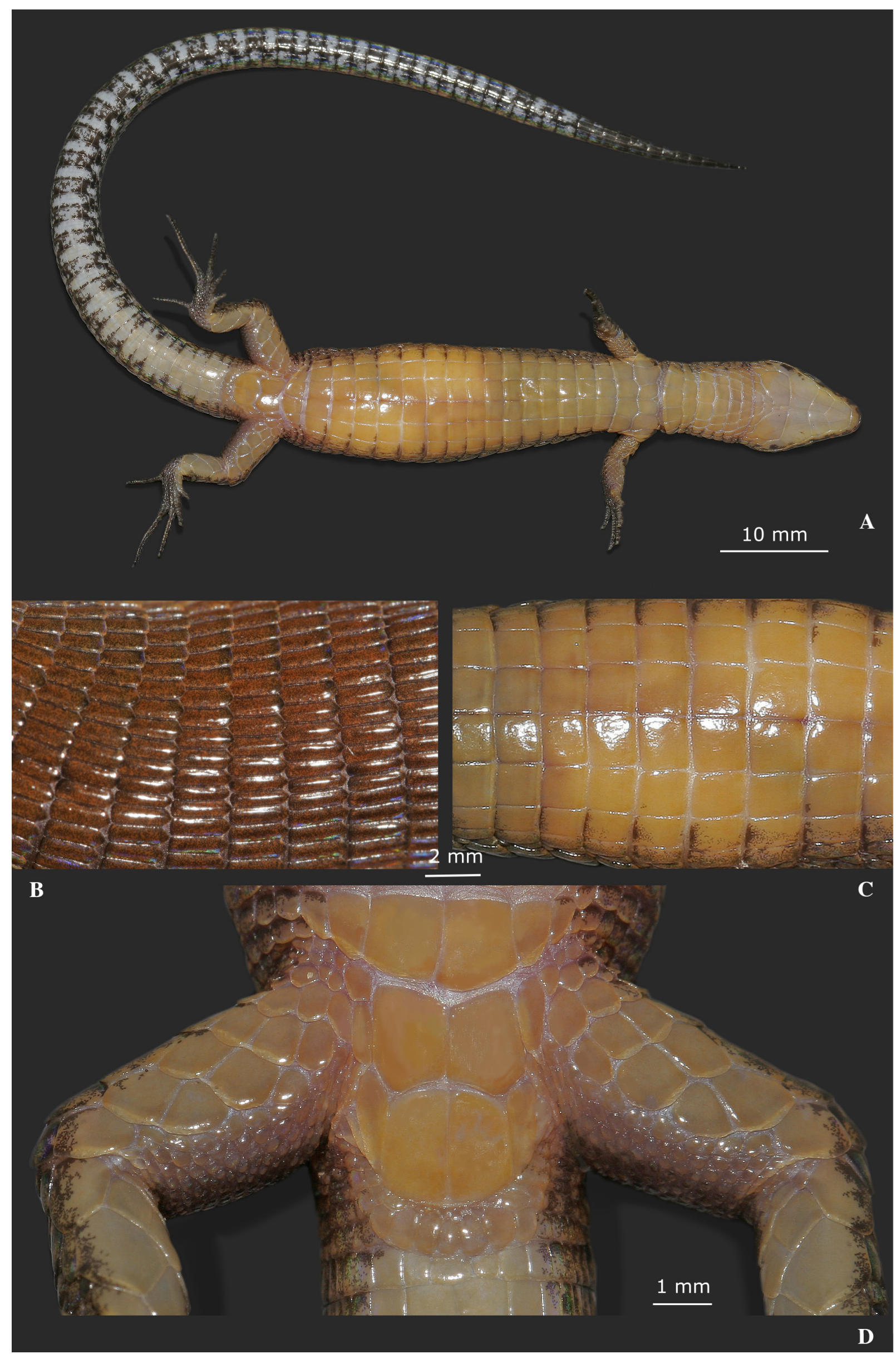

Figure 4. Adult female Ptychoglossus brevifrontalis from Mount Itoupé. A. Ventral aspect. B. Midtrunk view of dorsal scales. C. Midtrunk view of ventral scales. D. Subpelvic view. Photographs by Maël Dewynter. 


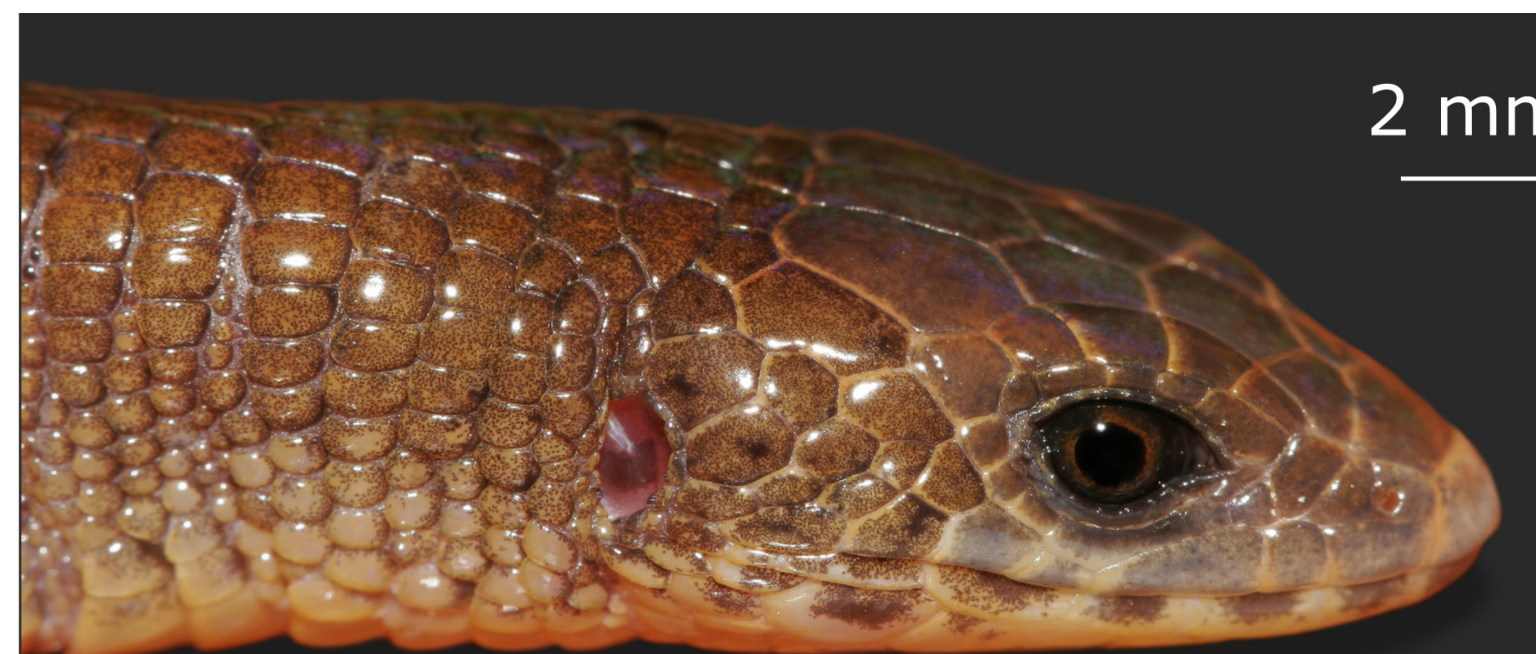

$\mathbf{A}$

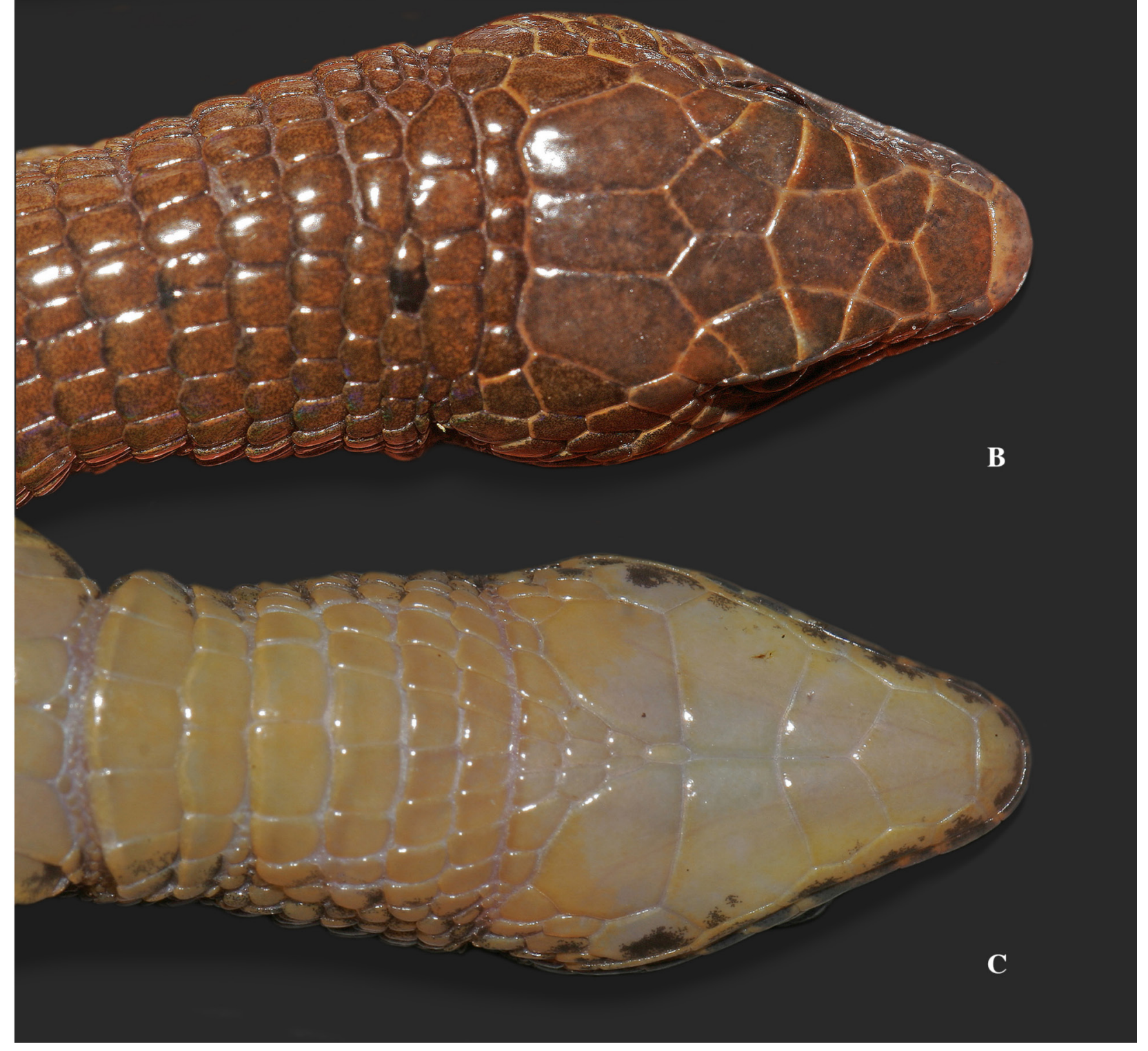

Figure 5. Adult female Ptychoglossus brevifrontalis from Mount Itoupé. A. Lateral. B. Dorsal. C. Ventral aspects of the head and neck scales. Photographs by Maël Dewynter. 
and Magazine of Natural History (Series 8) 10: 420-424. https:// doi.org/10.1080/00222931108692903

Carrillo de Espinoza N, Icochea J (1995) Lista taxonómica preliminar de los reptiles vivientes del Perú. Publicaciones del Museo de Historia Natural de la Universidad Nacional Mayor se San Marcos 49:1-27.

Dewynter M, Surugue N (2012) First record of Amapasaurus tetradactylus Cunha, 1970 (Squamata: Gymnophthalmidae) in French Guiana. Check List 8 (4):815-816. http://doi.org/10.15560/8.4.815

Dirksen, L, De la Riva I (1999) The lizards and amphisbaenians of Bolivia (Reptilia, Squamata): checklist, localities, and bibliography. Graellsia 55:199-215.

Duellman WE (1978) The biology of an Equatorial Herpetofauna in Amazonian Ecuador. Miscellaneous Publication of the. Museum of Natural History of the University of Kansas 65:1-352.

Dunn ER (1944) The lizard genera Anadia and Ptychoglossus in Colombia. Caldasia 3 (11):63-68.

Goicoechea N, Frost DR, De la Riva I, Pellegrino KC, Sites Jr J, Rodrigues MT, Padial JM (2016) Molecular systematics of teioid lizards (Teioidea/Gymnophthalmoidea: Squamata) based on the analysis of 48 loci under tree-alignment and similarity-alignment. Cladistics 32 (6): 624-671. https://doi.org/10.1111/cla.12150

Harris DM (1994) Review of the teiid lizard genus Ptycho- glossus. Herpetological Monographs 8: 226-275. https://doi. org/10.2307/1467082

Hoogmoed MS (1973) Notes on the herpetofauna of Surinam IV: the lizards and amphisbaenians of Surinam. Biogeographica 4 $1-419$.

Peloso PL, Ávila-Pires TC (2010) Morphological variation in Ptychoglossus brevifrontalis Boulenger, 1912 and the status of Ptychoglossus nicefori (Loveridge, 1929) (Squamata, Gymnophthalmidae). Herpetologica 66 (3): 357-372. https://doi. org/10.1655/09-048.1

Peters JA (1967) The lizards of Ecuador, a checklist and key. Proceedings of the United States National Museum 119 (3545): 1-49.

Pinto MGM, Quatman WE (2005) Ptychoglossus brevifrontalis (Boulenger's large-scaled lizard). Herpetological Review 36: 202.

Ribeiro-Junior MA, Amaral S (2017) Catalogue of distribution of lizards (Reptilia: Squamata) from the Brazilian Amazonia. IV. Alopoglossidae, Gymnophthalmidae. Zootaxa 4269 (2): 151-196. https://doi.org/10.11646/zootaxa.4269.2.1.

Sabatier D, Molino JF, Tarcy M, Prévost MF (2015) Flore et végétation du massif du mont Itoupé. Caractérisation des communautés végétales arborescentes. In: Parc Amazonien de Guyane 2015. Itoupé 2010. Les Cahiers Scientifiques du Parc, Dossier Spécial 2015: 84-125. 